\title{
Stachytarpheta indica Leaf Extract: Oral Acute Toxicity, In vitro Phytochemical and Antimicrobial Potentials
}

\author{
Achimugu Dickson Musa ${ }^{1}$, Cyril Ogbiko ${ }^{2, *}$, Musa Usman Dabai ${ }^{2}$, \\ Ibeabuchi Jude Ali ${ }^{3}$, Abubakar Sani Yelwa ${ }^{2}$ and Hafsat Bature Buhari ${ }^{2}$ \\ ${ }^{1}$ Department of Biochemistry, Ibrahim Badamasi Babangida University, Lapai, Nigeria \\ ${ }^{2}$ Department of Pure and Applied Chemistry, Faculty of Science, Usmanu Danfodiyo University Sokoto, \\ Sokoto State, Nigeria \\ ${ }^{3}$ Department of Pharmaceutical Chemistry, Enugu State University of Science and Technology, Enugu, \\ Nigeria \\ *Corresponding author e-mail: cyril.ogbiko@udusok.edu.ng; cyrilogbiko@ gmail.com
}

\section{Abstract}

This study was designed to ascertain the safety profile as well as explore new antimicrobial agents from the methanol leaf extract of Stachytarpheta indica. The methanol extract was prepared and screened for its phytochemical composition, oral acute toxicity profile as well as challenged with common pathogenic microorganisms for its antimicrobial activities using standard procedures. The phytochemical analysis revealed the presence of various pharmaceutically active secondary metabolites like alkaloids, saponins, carbohydrate, cardiac glycosides, terpenoid, tannin, anthraquinones, phenolics and flavonoid. P. aeruginosa and S. aureus showed the best and least antibacterial activity respectively. The extract exhibited antifungal activity in a dose dependent manner with the inhibition more pronounced with A. niger than with $C$. albicans. The standard drugs ciprofloxacin and fluconazole exhibited a near $100 \%$ activity. There was no mortality at $8 \mathrm{~g} / \mathrm{kg}$ p.o. after 24 hours and no sign of delayed toxicity or mortality after 14 days of observation. There were no statistically significant differences $(p>0.05)$ observed in the examined organs as well as body weights in both $24 \mathrm{~h}$ and $14 \mathrm{~d}$ study. This research holds promise for the exploration of various potentially active secondary

Received: July 1, 2019; Accepted: July 20, 2019

Keywords and phrases: antimicrobial, phytochemical, Stachytarpheta indica, toxicity, Verbenaceae.

Copyright () 2019 C. Ogbiko et al. This is an open access article distributed under the Creative Commons Attribution License, which permits unrestricted use, distribution, and reproduction in any medium, provided the original work is properly cited. 
metabolites which would help in developing pharmaceuticals especially antimicrobial drugs as well as recommend the short-term oral administration of the extract up to a dose of $8 \mathrm{~g} / \mathrm{kg}$ body weight.

\section{Introduction}

For centuries, natural products have provided medicine for human illness and most of these remedies were obtained from higher plants [1]. Across the globe, medicinal plants are potent source therapeutic drugs of which antimicrobial agents may be obtained [2]. The use of medicinal plants in West Africa is probably as old as the duration of human settlement in the region $[3,4]$. The reason for the use of herbs is because of their affordability, easy accessibility and effectiveness. In the last two centuries, there has being serious investigations into the chemical and biological activities of plants and these have yielded compounds for the development of synthetic organic chemistry and the emergence of medicinal chemistry as a route for the discovery of more effective therapeutic agents [5].

Stachytarpheta indica commonly known as snakeweed is belonging to the family Verbenaceae. It is a well branched herb 2-3 ft high with very long narrow spikes. The flowers are deep blue with white centre. They are drought tolerant suitable for xeriscaping. The plant has been used locally as an abortifacient and in the management of asthma, headache, alopecia, bronchitis, bruise, chest cold, constipation, itch, diarrhea, skin sore, vermifuge, dysentery, dysmenorrhea, erysipelas, fever, inflammation, liver disease, poisoning, tumor, venereal disease, cataract, sedative, anti-fertility, rheumatism among others $[6,7]$. In northern Nigeria, a decoction of the leaves with natron is given for dysentery in humans and for similar conditions in horses [7,8].The interest in the scientific investigation of Stachytarpheta indica leaves is based on the claims of their effective use for the treatment of many microbial infections. Therefore, research into the effects of this local medicinal plant is expected to enhance the use of the plants against diseases caused by the test pathogens. The active principles of many drugs found in plants are secondary metabolites $[9,10]$. The toxicity profile of plants provides necessary information to guide natural product's use. Therefore, basic phytochemical investigation of the extract for their major phytoconstituents is key. In the present study, the methanol extract from the plant leaf was screened for phytochemical constituents, oral acute toxicity and antimicrobial activity against Staphylococus aureus, Pseudomonas aeruginosa, Proteus vulgaris, Aspergillus niger and Candida albicans. 


\section{Materials and Methods}

\section{Collection and preparation of plant materials}

Fresh S. indica leaves were collected in June 2018 from a forest in Othame village in Etsako East local government area of Edo State Nigeria. They were washed running tap water to remove earthy material before being transported in a closed sterile polythene bag to the laboratory for further analysis. They were identified and authenticated at the Forest Research Institute of Nigeria (FRIN) Ibadan where an herbarium specimen was deposited. The fresh leaves were air-dried for a period of two weeks before being reduced to fine powder with the aid of a mortar and pestle. The powdered sample was stored in an air tight container until used.

\section{Phytochemical analysis}

Simple chemical tests to detect the presence of secondary metabolites were done in accordance with standard methods [11-13].

\section{Preparation of extract}

$500 \mathrm{~g}$ of the pulverized material was extracted with $2.0 \mathrm{~L}$ of methanol by maceration at room temperature for 72 hours. The methanol extract of $S$. indica (MESI) was concentrated to dryness using a rotary evaporator at $40^{\circ} \mathrm{C}$ under reduced pressure. The concentrated extract was air dried, weighed, stored in an air-tight glass container before being preserved in a refrigerator at $-4^{\circ} \mathrm{C}$ until ready for use.

\section{Animals procurement and treatment}

Twenty five (25) healthy wistar albino rats of either sex (non-pregnant females) weighing within 180-220 g were obtained from the animal house facility of the Department of Pharmacology, Faculty of Pharmaceutical Sciences, Usmanu Danfodiyo University Sokoto, Sokoto State, Nigeria. They were housed in plastic cages and fed with standard laboratory animal food pellets. Animals were exposed to natural lighting conditions and were handled in accordance with international principles guiding the use and handling of experimental animals. However, food was withdrawn $4 \mathrm{~h}$ before the start of the experiment. 


\section{Twenty-four (24) hour single dose and 14 days extract administration}

The procedure outlined by Ogbiko et al. [14] with slight modification was adopted. The rats were assigned to four groups of 5 rats per group. The treatment groups A, B, C and D received via oral route methanol leaf extract of $S$. indica (MESI) resolubilized in $10 \%$ tween 80 at a dose of 1,2, 4 and $8 \mathrm{~g} / \mathrm{kg} b w t$ respectively. Group E (the control group) received $10 \mathrm{~mL} / \mathrm{kg}$ of $10 \%$ tween 80 via the same route. After all administrations, the animals were observed for toxic manifestations for the next $4 \mathrm{~h}$ and subsequently were observed intermittently for signs of morbidity and mortality. Animals that survived after the 24 hours duration was observed further for 14 days for any sign of delayed toxicity. Body weights were taken before extract administration and after $24 \mathrm{~h}$ and 14 days duration. Animals that survived were exposed to chloroform anesthesia via inhalation for extraction of the kidney, liver, heart, and spleen.

\section{Observation and examination methods}

Signs for toxic manifestations like abnormal motor activity, alteration in water or food intake, writhing, straub reaction, sedation, diarrhoea, piloerection, opisthotonus, exophthalmos and tremors were observed for in all groups [15].

\section{Collection of the Microorganisms}

Hospital strains of Staphylococus aureus, Pseudomonas aeruginosa, Proteus vulgaris, Aspergillus niger and Candida albicans were collected from any of vaginal, urine, scars among others specimens.

\section{Confirmation of test organisms}

Biochemical analysis methods as described by MacFaddin [16], Fobres and Sham [17] and Leboffe and Pierce [18] were carried out on each of the test bacteria isolates for confirmation. The Bergey's Manual of Systematic Bacteriology [19] was used for species authentication. The fungi isolates of Aspergillus niger and Candida albicans was identified via macroscopic and microscopic observations as well as germ tube test and chlamydospore production on cornmeal agar fortified with Tween 80 polysorbate.

\section{Antimicrobial activity}

\section{Testing for antibacterial activity}

The agar well diffusion method described by Kavanagh [20] as modified by Ogbiko et al. [21] was employed to assess the antibacterial activity of the prepared extracts. 0.6 
$\mathrm{ml}$ of standardized bacterial stock suspensions of $10^{8}-10^{9}$ colony forming units per $\mathrm{ml}$ was thoroughly mixed with $60 \mathrm{ml}$ of sterile nutrient agar. $20 \mathrm{ml}$ of the inoculated nutrient agar were distributed into sterile petri dishes. The agar was left to set and in each of these plates, 7 cups, $10 \mathrm{~mm}$ in diameter, were cut using a sterile cork borer and the agar discs were removed. Five alternate cups were filled with $0.1 \mathrm{ml}$ of the MESI extracts with $20 \mathrm{mg} / \mathrm{mL}, 40 \mathrm{mg} / \mathrm{mL}, 60 \mathrm{mg} / \mathrm{mL}, 80 \mathrm{mg} / \mathrm{mL}$, and $100 \mathrm{mg} / \mathrm{mL}$ concentration prepared in DMSO using micropipette while the sixth and seventh cups contain DMSO (negative control) and the standard drug ciprofloxacin $(20 \mu \mathrm{g} / \mathrm{mL})$ in DMSO respectively. All cups were allowed to diffuse at room temperature for two hours. The plates were then incubated in the upright position at $37^{\circ} \mathrm{C}$ for 18 hours. Three replicates were carried out for each extract against each of the test organism with the zone of inhibition was the inhibitory parameter adopted.

\section{Testing for anti-fungal activity}

The same method as for bacteria was followed. Instead of nutrient agar media, yeast and mould extract agar was used. The inoculated medium was incubated at $25^{\circ} \mathrm{C}$ for two days for Candida albicans and three days for Aspergillus niger. This was carried out in triplicate for each fungus. Antibiotic susceptibility was carried out on DMSO and the test drug (fluconazole) to serve as negative and positive control respectively [21, 22].

\section{Statistical analysis}

All data are represented as the mean \pm standard error of mean (S.E.M.).The onefactor analysis of variance with Dunnett's post hoc testing for group differences was employed. Differences were considered to be significant when p-values were less than 0.05 .

\section{Results and Discussion}

\section{Percentage yield and phytochemical screening}

The percentage yield of the crude methanol extract was found to be $4.13 \%$. The phytochemical screening revealed the presence of important phytoconstituents presented in Table 1. 
Table 1. Phytochemical screening of the methanol extract of S. indica.

\section{Phytochemicals}

Alkaloids

Saponins

Carbohydrate

Cardiac glycosides

Terpenoid

Tannin

Anthraquinones

Phenolics

Flavonoids
Observation

Yellow precipitate formed

Yellow emulsion formed

Violet ring formed

Violet ring formed

Brown ring formed

Green black colour not seen

Green colour observed

Intense colouration

Yellow colour persist

\section{Inference}

$+$

$+$

$+$

$+$

$+$

$+$

$+$

$+$

$+$

This result validates the findings of Krishna [7] who reported the same phytochemicals in the methanol extract of the leaves of the plant. Secondary metabolites are known to impart characteristic odour, taste, colour, medicinal or poisonous properties on the plant [23] as well as aid in the biological actions for which they are identified in folk medicine [14].

\section{Oral acute toxicity screening}

The result of the toxicity profile of the methanol extract of $S$. indica (MESI) is indicated in Figure 1.

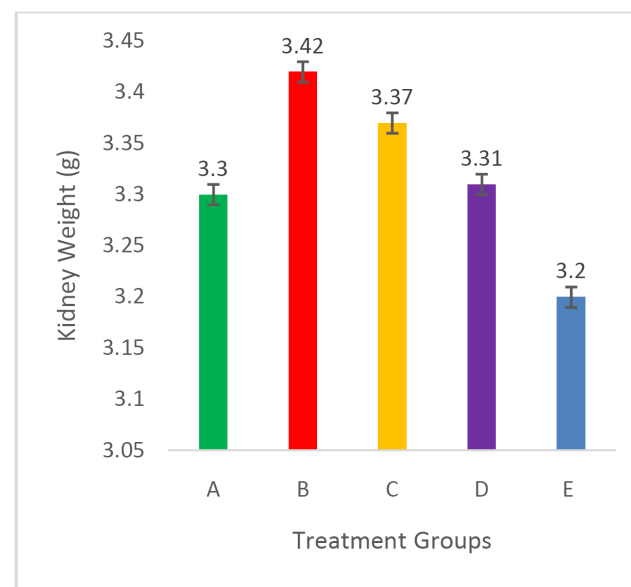

A

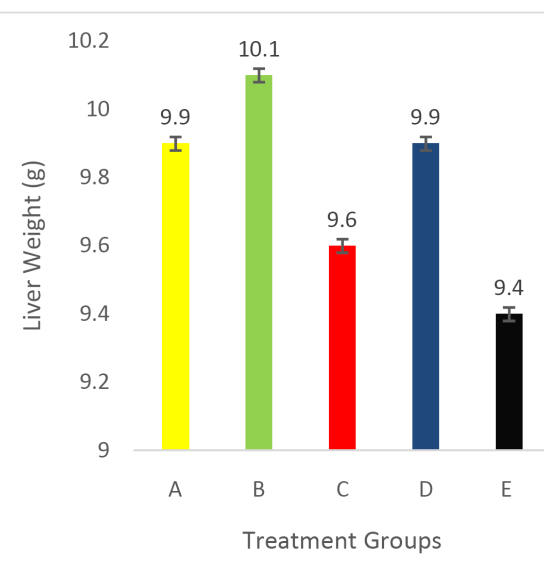

B 


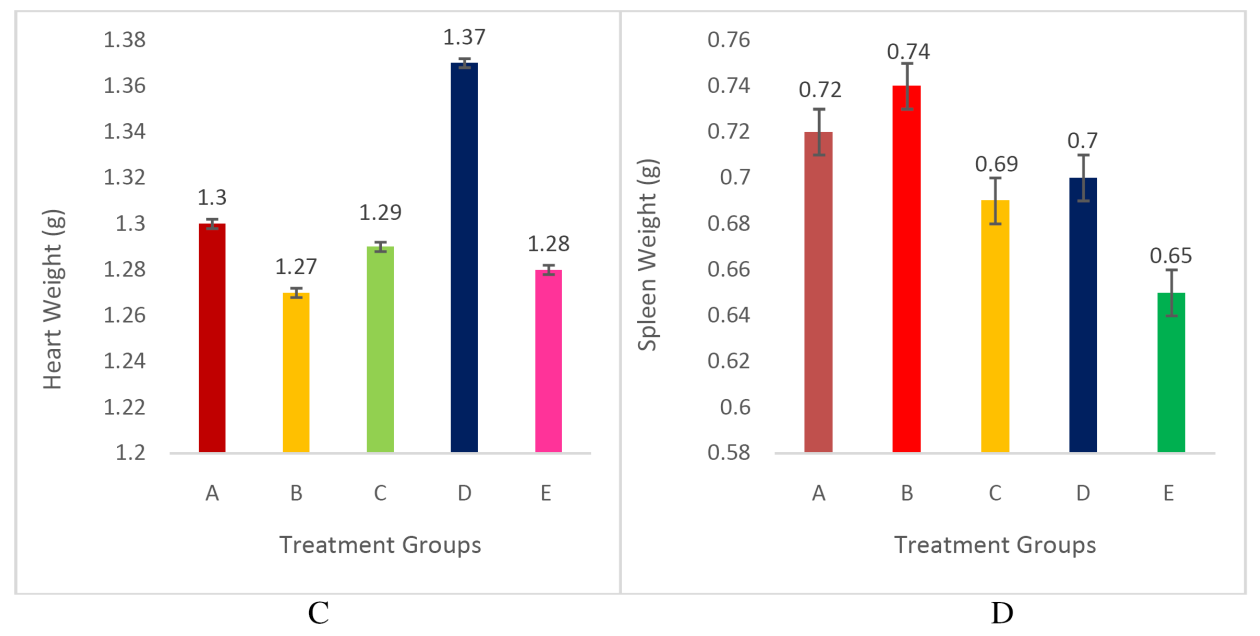

Figure 1. Bar graphs showing the weights of organs isolated after the 14 days experimental toxicity study for all groups. $n=5$ animals.

Key: The weights of the (A) kidney, (B) liver, (C) heart and (D) spleen.

After $24 \mathrm{~h}$ and 14 days observation period, there was no mortality or observed adverse reactions or mortality. The general behaviour remained the same throughout the time period. The LD50 which normally is the dose that will result in the death of 50\% of the population was found to be beyond $8 \mathrm{~g} / \mathrm{kg}$ hence therapeutic doses for the methanol extract of $S$. indica can be safely administered with the $0-8 \mathrm{~g} / \mathrm{kg}$ range. With the animals surviving up to a dose of $8 \mathrm{~g} / \mathrm{kg}$, it shows that no further acute testing is required as the test compound is considered safe [23-25]. There were no statistically significant differences in the body weights of animals in all groups after the 14 days study. This implies that the extract helps to maintain the health status of the animals since body weight changes serve as sensitive indications of general health of animals as well as no interference with normal metabolism which would also have affected food and water intake [26-28].The idea of weighing organs in toxicity testing is as a result of their linked correlation with histopathological changes [29]. For the organ weights analysis, there were no statistically significant differences between the control and treated groups of the organs collected, however the treatment groups were found to have a slight increase their weight when compared to the control group. The lack of significant changes in the organs suggests that administration of MESI on a short term may not alter normal growth and development. 


\section{Antibacterial and antifungal activity}

The result presented in Figure 2 reveals the in vitro susceptibility of the bacterial and fungal isolates at different concentrations of MESI in comparison to ciprofloxacin (20 $\mu \mathrm{g} / \mathrm{mL})$ and fluconazole standard $(100 \mu \mathrm{g} / \mathrm{mL})$ respectively.

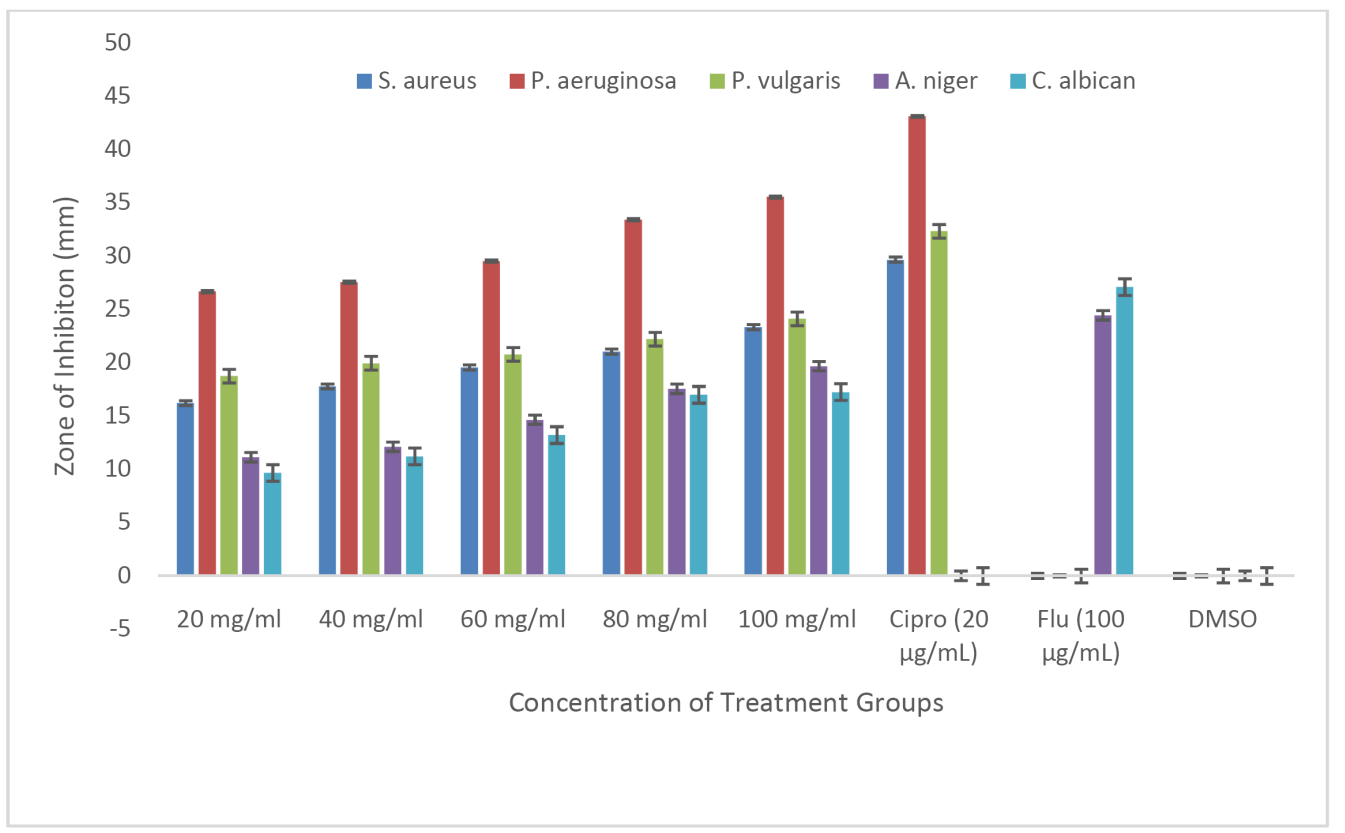

Figure 2. Antimicrobial activity (zone of inhibition) of $S$. indica methanol extract against various human pathogens in comparison with standard drugs.

Key: Cipro $=$ Ciprofloxacin, Flu $=$ Fluconazole, DMSO = Dimethyl sulphoxide

Natural antimicrobial compounds from plants act as therapeutics that can inhibit the growth of pathogens and have been used to overcome the side effects associated with the synthetic antimicrobial agents [21]. The MESI showed varying activity against the bacteria isolates investigated. While the best activity among the bacterial isolates investigated was exhibited by $P$. aeruginosa, the least activity was exhibited by the $S$. aureus. The result of the anti-fungal assay indicated that the fungal isolates were inhibited by MESI in a dose dependent manner with the inhibition more pronounced with A. niger than with C. albicans. Both ciprofloxacin and fluconazole exhibited a $100 \%$ or near $100 \%$ because it is known to contain purified compound [21]. The antimicrobial activity recorded is attributed to the presence of more group of phytochemicals diversity responsible for the synergic effects in many biological applications [21, 30]. The 
disparity between the activities of the extracts and the standard antimicrobial drugs may be due to the mixtures of bioactive compounds present in the extracts compared to the pure compound contained in the standard antibiotics [31].

\section{Conclusion}

The present study reports that $S$. indica is a good source of various metabolites responsible for the investigated antimicrobial activity in agreement with its folkloric claims. The study also showed that the oral administered extract of $S$. indica is relatively safe at the highest tested dose of $8 \mathrm{~g} / \mathrm{kg}$ in rats. Similarly, the plants demonstrating an appreciable broad spectrum of microbial activity which may help in the discovering of new chemical classes of antibiotics that could serve as selective agents for the maintenance of health. These results encourage the researchers to do further in vitro and in vivo research that will explore the role of bioactive constituents responsible for these activities as well as carry out studies at molecular level.

\section{References}

[1] M. Wink, T. Schmeller and B. Latz-Brüning, Modes of action of allelochemical alkaloids: interaction with neuroreceptors, DNA and other molecular targets, Journal of Chemical Ecology 24 (1998), 1881-1937. https://doi.org/10.1023/A:1022315802264

[2] J. P. Srivastava, J. Lambert and N. Vietmeyer, Medicinal plants: An expanding role in development, World Bank Technical Paper No. 320, 1996.

https://doi.org/10.1596/0-8213-3613-4

[3] F. I. Abdulrahman, J. C. Akan, O. A. Sodipo and P. A. Onyeyili, Effect of aqueous rootbark extract of Vitex doniana sweet on haematological parameters in rats, Journal of American Science 6 (2010), 8-12.

[4] O. A. Sodipo, F. I. Abdulrahman, U. K. Sandabe and J. A. Akinniyi, Effects of the aqueous fruit extract of Solanum macrocarpum Linn on the hematological parameters of triton-induced hyperlipidemic rats, African Journal of Pharmacy and Pharmacology 5(5) (2011), 632-639. https://doi.org/10.5897/AJPP10.288

[5] G. Roja and P. S. Rao, Anticancer compound from tissue cultures of medicinal plant, Journal of Herbs, Spices \& Medicinal Plants 7 (2000), 71-102. https://doi.org/10.1300/J044v07n02_08

[6] E. S. Ayensu, Medicinal Plants of West Africa, Algonac, Michigan: Reference Publication, Inc., 1978. 
[7] H. N. Krishna Kumar, Kokila, G. Bhavyashree and J. B. Chauhan, Phytochemical screening and antibacterial activity of Stachytarpheta indica, Global Journal of Pharmacology 6(1) (2012), 4-7.

[8] H. M. Burkill, The Useful Plants of West Tropical Africa, 2nd ed., Kew, UK: Royal Botanic Gardens, 1985, pp. 456-596.

[9] A. Ghani, Introduction to Pharmacognosy, Zaria, Nigeria: Ahmadu Bello University Press, Ltd., 1990, pp. 45-47, 187-197.

[10] I. N. Dobelis, Magic and Medicine of Plants, The Readers Digest Association Inc., Pleasant, New York, Montreal, 1993, pp. 8-48.

[11] E. Stalh, Drug Analysis by Chromatography and Microscopy. A Practical Supplement to Pharmacopoeias, 1st ed., Ann Arbor, Michigan, 1973, pp. 219-224.

[12] A. Sofowora, Screening plants for bioactive agents, in: Medicinal Plants and Traditional Medicine in Africa, Ibadan: Spectrum Books Ltd., 1982.

[13] G. E. Trease and W. C. Evans, Pharmacognosy, 11th ed., London: Churchill Livingstone Harcourt Health Service, 1978, pp. 60-75.

[14] C. Ogbiko, J. C. Eboka, I. Igbe and D. M. Usman, Anti-Ulcer activity of methanol extract of Plantago rugelii Decne. (Plantaginaceae), Tropical Journal of Natural Product Research 1(2) (2017), 84-88. https://doi.org/10.26538/tjnpr/v1i2.7

[15] E. E. Bafor, F. Ukpebor, O. Omoruyi, E. Ochoyama and K. Odega, Acute toxicological evaluations of the methanol leaf extract of Justicia flava (Vahl) Acanthaceae in mouse models, Trop. J. Nat. Prod. Res. 3(4) (2019), 138-144.

https://doi.org/10.26538/tjnpr/v3i4.6

[16] J. F. MacFaddin, Biochemical Tests for Identification of Medical Bacteria, 3rd ed., Washington, DC: ASM Press, 2000.

[17] B. D. Fobres and A. Sham Weissfield, Diagnostic Microbiology, 11th ed., Canada: Andrew Allen Press, 2002, pp. 56-59.

[18] M. J. Leboffe and B. E. Pierce, Microbiology Laboratory Theory and Application, 1st ed., USA: Morton Publishers, 2002, pp.76-79.

[19] P. H. A. Sneath, N. S. Mair, M. E. Sharpe and J. G. Holt, Bergey's Manual ${ }^{\circledR}$ of Systematic Bacteriology, Vol. 2, Philadelphia: Williams \& Wilkins, 1986.

[20] F. Kavanagh, Analytical Microbiology, Vol. 11, New York: Academic Press, 1972.

[21] C. Ogbiko, C. J. Eboka and A. D. Tambuwal, Extraction and fractionation of whole black 
seed plantain (Plantago rugelii Decne) for in-vitro antioxidant, antibacterial and phytochemical screening, Journal of Allied Sciences and Environment Management 22(5) (2018), 613-619. https://doi.org/10.4314/jasem.v22i5.1

[22] N. Sajid, B. Nizam, B. Sajid, R. Tahmina and M. S. A. Yasser, In vitro antimicrobial, antitumor, cytotoxic activities of methanolic extract and its fractions of Acantholimon longiscapum, Int. J. Phytopharmacol. 4(3) (2013), 179-183.

[23] National Research Council, Guide for the Care and Use of Laboratory Animals: Eighth Edition, in: Guide for the Care and Use of Laboratory Animals, National Academies Press, 2010.

[24] M. Porwal, N. A. Khan and K. K. Maheshwari, Evaluation of acute and subacute oral toxicity induced by ethanolic extract of Marsdenia tenacissima leaves in experimental rats, Sci. Pharm. 85(3) (2017), 29-35. https://doi.org/10.3390/scipharm85030029

[25] A. J. Akindele and E. L. Palmer, Effects of hydroethanolic leaf extract of Ipomoea asarifolia (Convolvulaceae) in Doxorubicin and isoproterenol-induced toxicity in rats, Trop. J. Nat. Prod. Research 2(2) (2018), 59-66. https://doi.org/10.26538/tjnpr/v2i2.2

[26] National Research Council, Toxicity Testing for Assessing Environmental Agents, Washington D.C., USA, 2006.

[27] R. Cancello, A. Tounian, C. Poitou and K. Clément, Adiposity signals, genetic and body weight regulation in humans, Diabetes Metab. 30(3) (2004), 215-227.

https://doi.org/10.1016/S1262-3636(07)70112-X

[28] J. El Hilaly, Z. H. Israili and B. Lyoussi, Acute and chronic toxicological studies of Ajuga iva in experimental animals, J. Ethnopharmacol. 91(1) (2004), 43-50.

https://doi.org/10.1016/j.jep.2003.11.009

[29] W. M. Kluwe, Renal function tests as indicators of kidney injury in subacute toxicity studies, Toxicol. Appl. Pharmacol. 57(3) (1981), 414-424.

https://doi.org/10.1016/0041-008X(81)90239-8

[30] J. Cooper, U. Niggli and C. Leifert, Handbook of Organic Food Safety and Quality, Cambridge, UK: Woodhead Publishing, 2006.

[31] D. Gatsing, C. F. N. Nkeugoauapi, B. F. N. Nkah, J. R. Kuiate and F. M. Tchouanguep, Chenopodium ambrosioides Linn. an indigenous medicinal plant, Afr. J. Pharm. and Pharmacol. 8(8) (2010), 231-234. 